\title{
Influence of Subinhibitory Concentrations of Honey on Toxic Shock Syndrome Toxin -1 (TSST-1) Production by Two Strains of Staphylococcus Aureus
}

\author{
Paulina Okoro, Shirley Coyle, Lorna Fyfe \\ Dietetics, Nutrition and Biological Sciences, Queen Margaret University, UK
}

Copyright (C) 2015 by authors, all rights reserved. Authors agree that this article remain permanently open access under the terms of the Creative Commons Attribution License 4.0 International License

\begin{abstract}
Antibiotic resistant bacteria are a worldwide health concern and it is essential to develop new antimicrobial agents to kill these bacteria and to reduce the use of antibiotics. Staphyloccus aureus (S.aureus) an important medical pathogen is responsible for many wound infections and up to $25 \%$ of all strains produce the toxic shock syndrome toxin (TSST-1) which stimulates the release of inflammatory cytokines which cause fever and shock. Here we report on the inhibition of two penicillin resistant TSST-1 producing strains of S.aureus by seven different honeys. Bacterial growth was reduced after 24 hours at $37^{\circ} \mathrm{C}$, from $10.0 \log _{10}$ in the TSB growth control to less than 1.0 $\log 10$ in Highland, Chilean and Manuka honey. TSST-1 production was reduced from $256 \mathrm{ng} / \mathrm{ml}$ in the TSB growth control to less than $30 \mathrm{ng} / \mathrm{ml}$ in sub inhibitory concentrations of all honeys.
\end{abstract}

Keywords Honey, S.aureus, TSST-1, Inhibition

\section{Introduction}

Staphylococcus aureus is a common pathogen associated with a large proportion of nosocomial and community acquired infections resulting in high morbidity and mortality. Diseases caused by this microbe include skin and soft tissue abscesses, toxic shock syndrome (TSS), scalded skin syndrome, food poisoning, pneumonia and septicaemia $[1,2]$. Treatment of diseases caused by $S$. aureus is difficult because of the emergence of multi- antibiotic resistant strains, including methicillin resistant $S$. aureus (MRSA) and vancomycin resistant $S$. aureus (VRSA) [3,4,5]. The ability of S.aureus to cause disease is largely dependent on the presence of extracellular virulence factors, including surface and secreted toxins [2]. Some of the most important and well studied extracellular virulence factors include four distinct haemolysins (alpha, beta, gamma and delta), toxic shock syndrome toxin - 1 (TSST-1), staphylococcal enterotoxins and exfoliative toxins, all of which have an effect on the host such as lysis of red blood cells, a reduction in blood pressure, vomiting, and exfoliation with blistering of the skin which can lead to life-threatening systemic illness [6,2].

Toxic Shock Syndrome Toxin -1 (TSST-1) is an exotoxin from the group of pyrogenic toxic super antigens and causes toxic shock syndrome (TSS) an acute and potentially deadly disease characterised by high fever, hypotension, skin rash and involvement of three or more organs [7]. The pathophysiology of TSS includes a release of cytokines and T-cell activation induced by TSST-1 and its direct effect on endothelial cells causing vasodilation resulting in hypotension [8].

Bacterial resistance to antibiotics has become a rapidly growing threat in both hospital and community settings, and the need to discover new an antimicrobial agent is very high. Honey has been used since ancient times in treatment of numerous diseases, including ulcers, abscesses, burns, and infected surgical wounds [9], however discovery of antibiotics in the early $20^{\text {th }}$ century lead to a move away from most of the natural treatments for infection. The current need for alternative antimicrobial agents has lead to increased research into re-examining natural treatments for infections $[10,11]$. Honey has been shown to be highly antibacterial $[12,13]$, in addition there is no evidence that bacteria which are inhibited by honey then become resistant to it . There are two registered medicinal honeys: Manuka and Revamil which are used in hospitals in North America, New Zealand, the Netherlands and Scotland.

There are many studies on the composition of honey $[14,15]$ and there is clear evidence which demonstrates the activity of some of these components. The antibacterial property of honey is, in part, due to the high content of sugar, low water activity, acidic $\mathrm{pH}$, presence of hydrogen peroxide $\left(\mathrm{H}_{2} \mathrm{O}_{2}\right)$, antioxidants and polyphenols, methylglyoxal (MGO) which is found in high concentration in Manuka honey and bee defensin-1 [16,13]. The botanical origin of honey also determines activity [17], indeed a Scottish Heather honey is as antibacterial as Manuka honey [18].It is not yet fully 
understood what exactly makes some honeys better than others and all the components and mechanisms of activity, including possible synergistic activity of active ingredients [19] have not yet been fully elucidated. However, a compositional analysis of honey indicates that, in general, high antibacterial activity is associated with darker honeys which are rich in polyphenols and antioxidants [13].

Despite all the research into antibacterial effects of honey, less is known about its effects on the production of bacterial pathogenicity and virulence factors. This study describes the influence of seven different honeys, with different antibacterial activity, on the production of TSST-1 by two strains of S.aureus. A compositional analysis of each honey was also made to determine whether this could be associated with antibacterial and anti-TSST -1 activity.

\section{Materials and Methods}

\subsection{Bacteria}

Two penicillin resistant TSST-1 secreting stains were used: Staphylococcus aureus NCTC 11965 and NCTC 11962 . Both were supplied by the National Collection Type Culture, Porton Down, Salisbury, UK.

\subsection{Honey Samples}

Comvita Manuka Medihoney ${ }^{\circledR}(\mathrm{MH})$, a honey derived mostly from Leptospermum spp, was used as a positive control. A sugar honey, based on the sugar composition of Remavil honey (Bee Factory Health Products, Rhenen, the Netherlands), was used as a negative control and consisted of $38.5 \%$ fructose, $33.3 \%$ glucose, $6.2 \%$ maltose and $7.3 \%$ sucrose in distilled water. Chilean honey $(\mathrm{CH})$, an antiseptic honey 20+, was obtained from the Active Honey Co, Unit 1 Elizabethan Way, Lutterworth, Leicestershire, LE17 4ND England. Colonsay Honey (COL) was purchased from Isle of Colonsay Scottish Bee Sanctuary. Buckwheat honey (BW) was produced in Poland by Huzar Sp. Z o. o., Nowy Sacz, and purchased from a Polish shop in Edinburgh, Scotland.

Highland honey (HL) from the Scottish Highlands, Heather honey (HE) from a Heather moorland in Morayshire in Scotland and Capestone Valley blossom honey (CV) from Scotland were kindly donated by Beekeepers.

\subsection{Microbiological Analysis of Honey}

\subsubsection{Comparison of the antimicrobial activity of honeys in vitro using a broth culture assay}

A broth culture assay was used to determine the inhibitory activity of honey against both TSST-1 secreting strains of S.aureus. Schneider et al. [13] found that honey broths of $75 \%$ honey in Tryptone Soy Broth (TSB), (Oxoid Ltd, United Kingdom) effectively reduced the number of colony forming units $(\mathrm{cfu}) / \mathrm{ml}$ of bacteria. Therefore, for comparative purposes broth cultures were prepared by inoculating $10 \mathrm{ml}$ of $75 \%$ honey broths with $100 \mu \mathrm{L}$ of an overnight starting TSB culture of each bacterium. Inoculated broths were incubated aerobically for 24 hours at $37^{\circ} \mathrm{C}$ with shaking in an orbital mixer. Broths were sampled and then serially diluted using $0.1 \mathrm{M}$ Phosphate Buffered Saline (PBS) before being spread onto TSA plates and again incubated for 24 hours at $37^{\circ} \mathrm{C}$. Plates with between 30 and $300 \mathrm{cfu}$ were counted. The sugar control honey was also investigated as well as the TSB growth control. All readings were made in triplicate and experiments were conducted on three separate occasions.

\subsubsection{Preparation of cultures and culture supernatants for TSST-1 assay}

Tryptone soya broths (TSB), containing subinhibitory concentrations of honey (5\% Manuka, 20\% Highland, 20\% Chilean, 30\% Colonsay, 20\% Heather, 20\% Buckwheat, $20 \%$ Capstone Valley and 30\% Sugar Control), were inoculated with $100 \mu \mathrm{l}$ of an overnight TSB culture of a TSST-1 secreting $S$. aureus. These subinhibitory concentrations were selected as they ensured that the bacterial count after $24 \mathrm{~h}$ in the experimental sample was similar to the number of bacteria in the TSB growth control. This ensured that any change in the amount of TSST-1 produced by S.aureus was a true reflection of the activity of the honey and not just because there was a substantial reduction of bacterial numbers in each honey compared to the growth control [20,21]. Supernatants from 24 hour cultures were obtained by centrifugation $(1600 \mathrm{~g})$ for $20 \mathrm{~min}$ and retained for determination of TSST-1.

\subsubsection{Determination of TSST-1 production by $S$. aureus}

TSST-1 was measured in culture supernatants using a reverse passive latex agglutination (RPLA) kit from Oxoid Ltd, United Kingdom. Measurements were made according to the manufactures instructions. Supernatants from subinhibitory honey cultures, the sugar control, and the TSB growth control prepared from three separate experiments were analysed in duplicate on each 96 well micro-titre plate.

\subsubsection{Determination of intracellular TSST-1 concentration after culture of S.aureus with subinhibitory concentrations of honey}

In order to investigate the mode of action of honey on the production of TSST-1, experiments based on those described previously Smith-Palmer et al. [20,21]were conducted to determine whether culture with honey prevented TSST-1 synthesized in the bacterial cell being exported across the bacterial cell wall into the culture supernatant.

S. aureus was cultured with subinhibitory concentrations of honey for 24 hours described previously, then centrifuged at $1600 \mathrm{~g}$ for $20 \mathrm{~min}$. The supernatant was discarded, bacteria were washed twice in $0.1 \mathrm{M}$ PBS and resuspended in $10 \mathrm{ml}$ PBS. Bacteria were then lysed on ice by sonication for $5 \mathrm{~min}$ and examined via light microscopy to ensure that all the cells 
were lysed. The lysate was examined for presence of TSST -1 using the RPLA kit described above.

\subsection{Compositional Analysis of Honey}

Each honey was analysed using the methods described below which are based on those described by Schneider et al [13].

\subsubsection{Estimation of Sugar content using Refractometry}

The total sugar content of each honey was determined using a pocket refractometer (Bellingham and Stanley Limited, United Kingdom) according to the manufacturer's guidelines. The sugar control honey was used to calibrate the refractometer before use.

\subsubsection{Estimation of $\mathrm{pH}$}

$\mathrm{pH}$ was measured using a standard laboratory $\mathrm{pH}$ electrode (Hanna Instruments, United Kingdom, Model $\mathrm{H} 18519 \mathrm{~N} \mathrm{pH}$ meter) which was calibrated before use with buffers $\mathrm{pH} 7.0$ and 3.0.

\subsubsection{Honey colour}

This was determined using the method described by Kaškonienè et al. [22]. Honey samples were diluted to $50 \%$ and heated up to $40^{\circ} \mathrm{C}$ to dissolve all the sugar crystals The absorbance of the sample was read at $635 \mathrm{~nm}$ and converted to mmPfund scale using equation:

$$
\mathrm{mmPfund}=-38.70+371.39 \times \mathrm{Abs}
$$

and then classified using United States Standards for Grades of Extracted Honey (United States. Agricultural Marketing Service. Fruit and Vegetable Division Processed Products Branch 1985). All honeys were also photographed.

\begin{tabular}{|c|c|}
\hline Colour Name & Pfund Scale, \\
\hline Water White & $<9$ \\
\hline Extra White & $9-17$ \\
\hline White & $18-34$ \\
\hline Extra Light Amber & $35-50$ \\
\hline Light Amber & $51-85$ \\
\hline Amber & $86-114$ \\
\hline Dark Amber & $>114$ \\
\hline
\end{tabular}

\subsubsection{Antioxidant capacity - ferric ion reducing power} (FRAP assay)

The FRAP reagents were prepared freshly before the experiment in accordance with the method described by Benzie and Strain [23].In brief, $100 \mathrm{ml}$ of $300 \mathrm{mM}$ of acetate buffer (pH 3.6) was mixed with $10 \mathrm{ml}$ of $10 \mathrm{mM}$ TPTZ solution in $40 \mathrm{mM} \mathrm{HCl}$ and $10 \mathrm{ml}$ of $20 \mathrm{mM} \mathrm{FeCl}_{3}$ solution. The reagent was then warmed up to $37^{\circ} \mathrm{C}$. Aliquots of $10 \mu \mathrm{l}$ of honey were pipetted into 96 well plate and mixed with $250 \mu \mathrm{l}$ FRAP reagent. Distilled water and serial dilutions of known ferrous sulphate served as a control. After incubation for 4 minutes absorbance at was read at $593 \mathrm{~nm}$, Aqueous solutions of known ferrous sulphate concentrations in the range 0.1 to $1.0 \mathrm{mM}$ were used for calibration and preparation of the standard curve.

\subsubsection{Total phenolic content - Folin and Ciocalteau method}

In this method total phenolic content was measured using Gallic acid as a standard [24]. Briefly, 100 $\mu$ of honey was diluted with $900 \mu \mathrm{l}$ of distilled water and $5 \mathrm{ml}$ of Folin and Ciocalteau reagent. The concentration of total phenolic content was calculated as milligrams of gallic acid equivalents per kilogram (mg GAE $/ \mathrm{kg}$ ) of honey, using a gallic acid standard curve.

\subsubsection{Hydrogen Peroxide $\mathrm{H}_{2} \mathrm{O}_{2}$}

Hydrogen peroxide was measured using a modified method previously described White and Subers [25] and Kwakman et al.[26] . In brief, honeys were diluted to $40 \%$ concentrations with PBS, and incubated in orbital incubator at $37^{\circ} \mathrm{C} 100 \mathrm{RPM}$ for $2.5 \mathrm{~h}$. The assay was performed in 96 well plates, $40 \mu \mathrm{l}$ of sample was added and $135 \mu$ l of reagent containing $50 \mu \mathrm{g} / \mathrm{ml}$ o-dianisidine (Sigma) and $20 \mu \mathrm{g} / \mathrm{ml}$ horseradish peroxidase type I (HRP-I) in $10 \mathrm{mM}$ phosphate buffer ( $\mathrm{pH} 6.5$ ). Absorbance was read at $430 \mathrm{~nm}$ at 0 hours (used as a blank) and after 2.5 and 5 hours.

Experimental honey results were calculated as the mean of triplicate readings taken at 2.5 and 5 hours and were described in $\mathrm{ug} / \mathrm{ml}$ using a hydrogen peroxide standard curve.

\subsection{Statistical Analysis}

For experimental reproducibility and statistical analysis, all readings were made in triplicate, and experiments were conducted on three separate occasions. Data was recorded as mean with standard error (SEM) and was analysed in SPSS 19.0 and Microsoft Excel 2010. Experimental data was compared to corresponding growth controls using a two-tailed independent Students' t-test. A p value of $\leq 0.05$ was accepted as significant. Ethical approval for this project was granted by the Division of Health Sciences Ethics Committee, Queen Margaret University.

\section{Results}

\subsection{Microbiological Experiments}

\subsubsection{Comparison of the antimicrobial activity of $75 \%$ honeys in vitro using a broth culture assay.}

Antibacterial properties of each $75 \%$ honey and the sugar control were assessed by the broth culture method with the results shown in Figure 1. Three most active honeys were Manuka, Highland and Chilean, with significant reduction in growth from approximately 10.0 to $9.00 \log _{10} \mathrm{cfu} / \mathrm{ml}$ in the TSB growth control for both strains of S.aureus, to less than $1.0 \log 10 \mathrm{cfu} / \mathrm{ml}(\mathrm{p}<0.001)$. There was no significant 
difference in the activity of each of these three honeys and they were significantly more active than the other honeys and the sugar control.

The next most active honeys were Capstone Valley, Heather and Buckwheat honey with a significant reduction in growth to $4.0 \log _{10} \mathrm{cfu} / \mathrm{ml}$ or less for both strains of bacteria. Although Colonsay honey and the sugar honey control were the least active there was still a significant reduction in growth to $5.0 \log _{10} \mathrm{cfu} / \mathrm{ml}$.

\subsubsection{Bacterial cell numbers and TSST production in subinhibitory concentrations of honey.}

The results from this experiment are shown in Table 1.

For each strain of S.aureus there was no significant difference in the bacterial count after 24 hours of culture in subinhibitory concentrations of honey or the sugar honey control compared to the TSB growth control with the exception of Manuka honey where there was more bacteria( $\mathrm{cfu} / \mathrm{ml}$ ) compared to the TSB control .

All honeys significantly reduced TSST-1 production by both strains of S.aureus $(\mathrm{p}<0.001)$ from more than $256 \mathrm{ng} / \mathrm{ml}$ in the TSB growth control to less than 30ng for Manuka and less than $18 \mathrm{ng}$ for all other honeys $(\mathrm{p}<0.001)$. In general, Highland honey and Heather honey were the most inhibitory for both strains of S.aureus where there was less than 11 $\mathrm{ng} / \mathrm{ml}$ of TSST-1 in each case. The sugar control had no measurable impact on TSST-1 production compared to the TSB growth control.

\subsubsection{Intracellular TSST-1 concentration after culture of S.aureus with subinhibitory concentrations of honey.}

When both strains of S.aureus were cultured for 24 hours with subinhibitory concentrations of each honey ( $\mathrm{MH}, \mathrm{HL}$, $\mathrm{CH}$, Colonsay honey, HE, Buckwheat honey, and Capstone Valley honey) TSST-1 was not detected in any bacterial cell lysate.

\section{Antimicrobial Properties of honey}

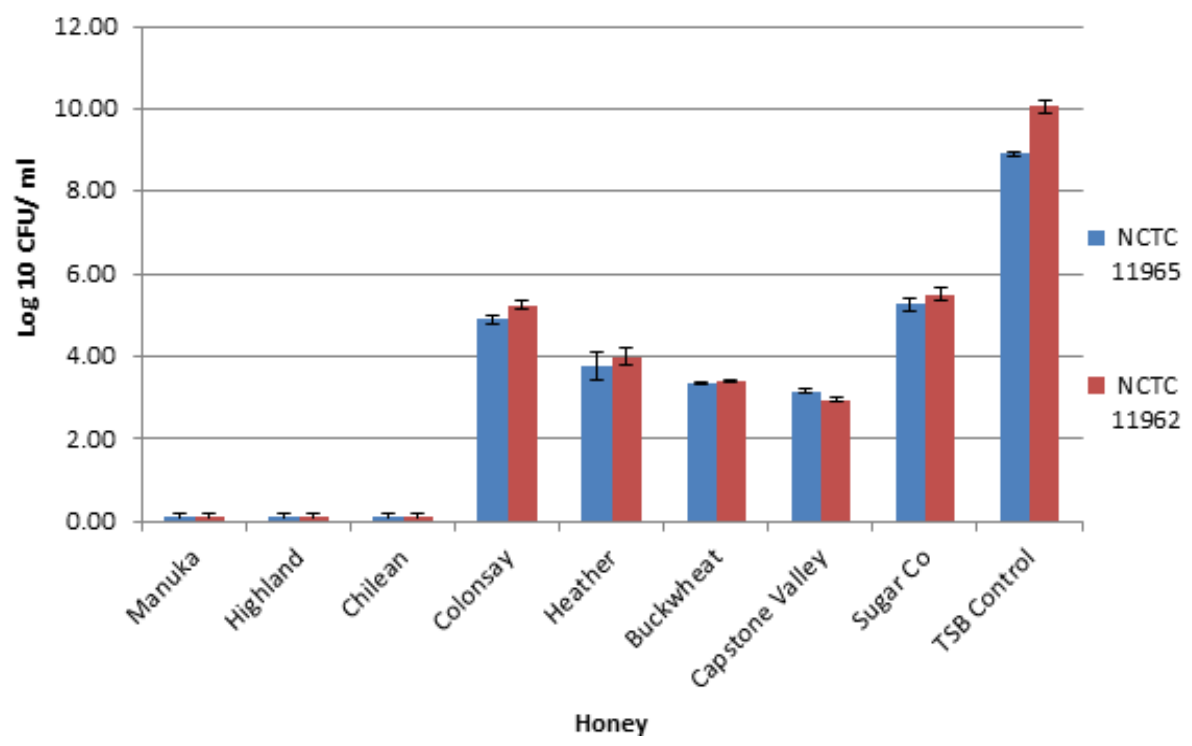

Figure 1. Inhibition of growth of two TSST-1 secreting strains of S.aureus in 75\% honey in TSB. Results are expressed as the mean with the SEM of log 10 $\mathrm{cfu} / \mathrm{ml}$ after incubation at $37^{\circ} \mathrm{C}$ for 24 hours. Experimental data for each honey and the sugar control, was compared to the TSB growth control

Table 1. Number of S.aureus expressed as $\log _{10} \mathrm{cfu} / \mathrm{ml}$ after culture in subinhibitory concentrations of honey for 24 hours at $37^{\circ} \mathrm{C}$, and TSST-1 concentration in corresponding culture supernatants.

\begin{tabular}{|c|c|c|c|c|}
\hline HONEY & $\begin{array}{c}\text { NCTC } 11965 \log _{10} \\
(\mathrm{cfu} / \mathrm{ml})\end{array}$ & $\begin{array}{c}\text { NCTC 11965 } \\
(\text { TSST-1ng/ml } \pm \text { SEM })\end{array}$ & $\begin{array}{c}\text { NCTC 11962 } \log _{10} \\
(\mathrm{cfu} / \mathrm{ml})\end{array}$ & $\begin{array}{c}\text { NCTC 11962 } \\
(\text { TSST-1ng/ml } \pm \text { SEM })\end{array}$ \\
\hline $5 \%$ Manuka & $9.19 \pm 0.02 *$ & $29.33 \pm 2.67 *$ & $9.06 \pm 0.05 *$ & $29.33 \pm 2.67 *$ \\
\hline $20 \%$ Highland & $8.96 \pm 0.01$ & $6.67 \pm 0.84 *$ & $8.40 \pm 0.12$ & $10.67 \pm 2.46 *$ \\
\hline $20 \%$ Chilean & $8.46 \pm 0.04$ & $12.00 \pm 1.79 *$ & $8.72 \pm 0.04$ & $13.33 \pm 3.96 *$ \\
\hline $30 \%$ Colonsay & $8.85 \pm 0.03$ & $6.00 \pm 0.89 *$ & $8.84 \pm 0.01$ & $14.67 \pm 3.82 *$ \\
\hline $20 \%$ Heather & $8.91 \pm 0.01$ & $8.00 \pm 1.79 *$ & $8.75 \pm 0.18$ & $9.33 \pm 2.23 *$ \\
\hline $20 \%$ Buckwheat & $8.79 \pm 0.17$ & $6.67 \pm 0.84 *$ & $8.45 \pm 0.22$ & $14.67 \pm 3.82 *$ \\
\hline $20 \%$ Capstone Valley & $8.96 \pm 0.02$ & $12.00 \pm 1.79 *$ & $8.91 \pm 0.04$ & $17.33 \pm 4.81 *$ \\
\hline $30 \%$ Sugar Co & $8.62 \pm 0.25$ & $>256.00 \pm 0.00$ & $8.84 \pm 0.02$ & $>256.00 \pm 0.00$ \\
\hline TSB Control & $8.93 \pm 0.04$ & $>256.00 \pm 0.00$ & $8.96 \pm 0.15$ & $>256.00 \pm 0.00$ \\
\hline
\end{tabular}

*Result significantly different from TSB control 
Table 2. Compositional analysis of honey.

\begin{tabular}{|c|c|c|c|c|c|c|}
\hline & Polyphenols $(\mathrm{mg} / \mathrm{L} \mathrm{GAE})$ & Antioxidants $\left(\mathrm{mM} \mathrm{Fe}^{2+} / \mathrm{L}\right)$ & $\mathrm{H}_{2} \mathrm{O}_{2}(\mathrm{ug} / \mathrm{ml})$ & $\mathrm{pH}$ & sugar & colour \\
\hline Manuka & $1282.47 \pm 25.68 *$ & $4.56 \pm 0.14 *$ & $3.35 \pm 1.38 \times$ & 3.00 & $78 \%$ & Amber \\
\hline Highland & $702.83 \pm 15.15 *$ & $1.39 \pm 0.06^{*}$ & $1.44 \pm 0.03 *$ & 3.00 & $79 \%$ & Light Amber \\
\hline Chilean & $867.32 \pm 28.43 *$ & $3.01 \pm 0.15^{*}$ & $74.5 \pm 11.6 *$ & 4.00 & $80 \%$ & Light Amber \\
\hline Colonsay & $1184.94 \pm 22.68 *$ & $10.55 \pm 0.11^{*}$ & $2.25 \pm 0.29 \times$ & 5.00 & $81 \%$ & Light Amber \\
\hline Heather & $824.86 \pm 20.69 *$ & $2.23 \pm 0.05^{*}$ & $35.63 \pm 7.49 *$ & 5.00 & $77 \%$ & Light Amber \\
\hline Buckwheat & $2034.65 \pm 53.90^{*}$ & $6.17 \pm 0.10^{*}$ & $26.7 \pm 3.34 *$ & 3.00 & $79 \%$ & Dark Amber \\
\hline Capstone V. & $240.75 \pm 11.36 *$ & $0.69 \pm 0.03 *$ & $244.87 \pm 41.59 *$ & 5.00 & $81 \%$ & White \\
\hline
\end{tabular}

*Significantly different from all other values, $\mathrm{P} \leq 0.05$

$\times$ not significantly different from each other

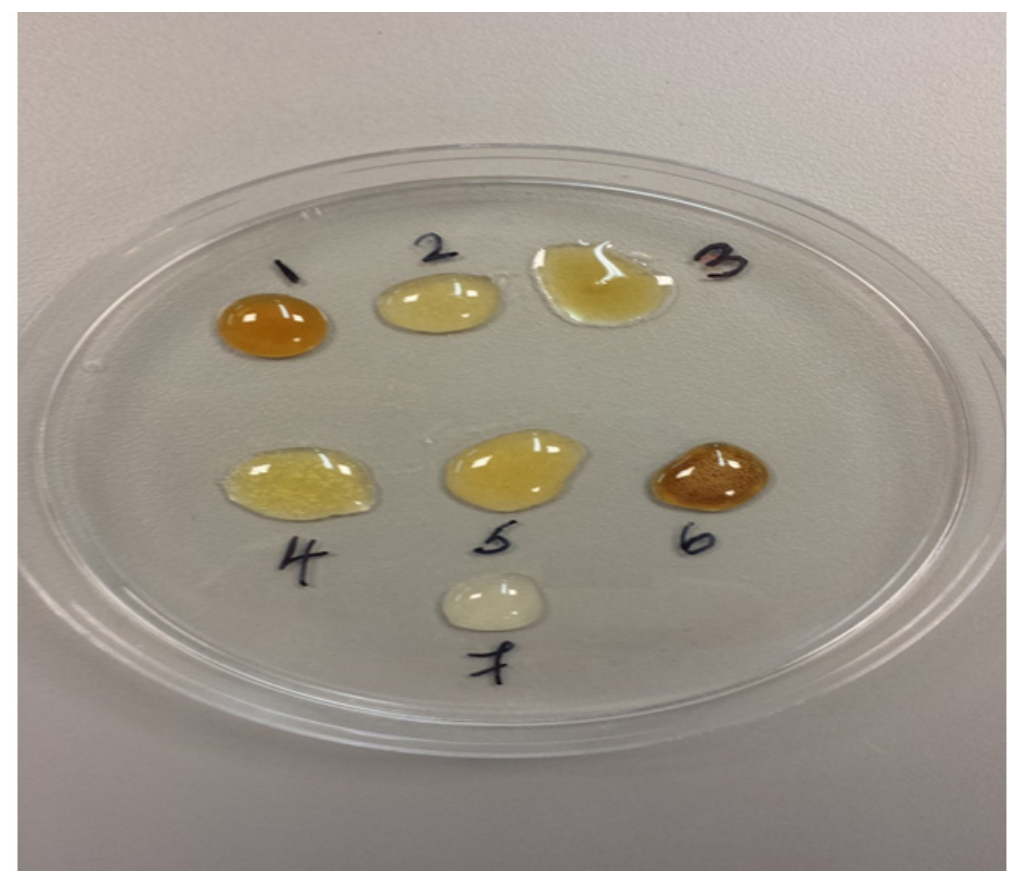

Supplementary Figure 1. Colour of honeys : 1. Manuka ; 2. Highland ; 3. Chilean ; 4. Colonsay; 5. Heather ; 6. Buckwheat ; 7.Capestone Valley.

\subsection{Biochemical and Compositional Analysis of Each Honey}

The composition of each honey is presented in Table 2 . All honeys had high sugar content $(\geq 75 \% \mathrm{w} / \mathrm{v})$ and an acidic $\mathrm{pH}$ between 3 and 5 .

There was a wide range in total polyphenols with the highest concentration of $2034 \mathrm{mg} / \mathrm{L}$ GAE for Buckwheat honey and the lowest of $240 \mathrm{mg} / \mathrm{L}$ GAE for Capstone Valley honey. Manuka and Colonsay honey both had total phenolics over $1000 \mathrm{mg} / \mathrm{L}$ GAE with Chilean, Heather and Highland honey between 700 to $800 \mathrm{mg} / \mathrm{L}$ GAE.

The range of antioxidant capacity of the honeys, in general, matched the range for the total polyphenols where high antioxidant capacity of $6.17\left(\mathrm{mM} \mathrm{Fe}^{2+} / \mathrm{L}\right)$ was measured in Buckwheat honey and the lowest activity of only $0.69(\mathrm{mM}$ $\mathrm{Fe}^{2+} / \mathrm{L}$ ) in the Capestone Valley honey.

There was a wide range of $\mathrm{H}_{2} \mathrm{O}_{2}$ content of the honeys which varied from the highest concentration of $245 \mathrm{ug} / \mathrm{ml}$ for Capestone Valley honey, to the lowest concentration of $<3.4$ $\mathrm{ug} / \mathrm{ml}$ for Manuka, Colonsay and Highland honey.
Most honeys were light amber in colour, but amber for Manuka honey, dark amber for Buckwheat honey, and white for Capestone Valley honey as shown in Supplementary Figure 1.

\section{Discussion}

The data presented here, shows the ability of seven honeys to significantly reduce the amount of TSST- 1 produced by two strains of $S$. aureus. The observed decrease in the amount of toxin in the supernatant from the subinhibitory concentration of each honey was not the result of a decrease in $\mathrm{cfu} / \mathrm{ml}$ of bacteria as there was no significant decrease in $\mathrm{cfu} / \mathrm{ml}$ in honey treated bacteria compared to the number of bacteria $\mathrm{cfu} / \mathrm{ml}$ in the TSB control ( see Table 1). Indeed for Manuka honey at 5\%, there were more bacteria $9.19 \log _{10}$ in this culture compared to $8.93 \log 10$ in the TSB growth control yet there was a significant decrease in TSST-1 production to $29.33 \mathrm{ng} / \mathrm{ml}$ in the Manuka culture compared to $>256 \mathrm{ng} / \mathrm{ml}$ in the TSB growth control. Jenkins et al. 
[27]demonstrated that Manuka honey down-regulated the expression of a number of virulence factors genes of S.aureus which included those for alpha and gamma haemolysins, enterotoxin $\mathrm{C}$ and a leucocidin, however down-regulation of the TSST-1 coding genes ( tst ) was not measured.by these authors. Several environmental factors such as anaerobic conditions [28, 29] and 1 molar sodium chloride [30] have been shown to decrease the production of TSST-1 by S.aureus as well as the combination of flucloxacillin and gentamicin [31].

It is not clear which components of honey reduced the production of TSST-1 in this study, it certainly was not sugar, as the sugar control honey failed to inhibit toxin production, and levels observed were the same as the TSB growth control. This is in contrast with results described by Chan and Foster [30] where $20 \mathrm{mM}$ sucrose strongly inhibited the expression of the tst gene in transcriptional reporter gene fusions. Unfortunately the level of the actual gene product (the TSST-1 toxin) was not measured by these authors, furthermore, the reporter fusion model is somewhat artificial as the normal interaction of honey and its respective components with S.aureus is absent. Further studies are clearly required to identify the active ingredient (s) in honey which reduces the production of TSST-1. Indeed, it is not evident from the compositional analysis of each honey whether there is an association with TSST-1 reduction and the concentration of polyphenol, antioxidant capacity, or $\mathrm{H}_{2} \mathrm{O}_{2}$ as these vary widely for each honey.

In this study, the precise inhibitory mechanism of action of the seven honeys on TSST-1 could have occurred at a number of points in the synthesis of the toxin including transcription, translation or export of the toxin from the bacterial cell. The lack of toxin detected when bacteria were lysed after culture in all honeys suggests it was unlikely there was an intracellular accumulation of TSST-1 resulting from the cells' inability to successfully export the toxin $[20,21]$ therefore inhibition was most likely to have occurred at transcription or translation which will be investigated in future studies.

With respect to the antibacterial properties of each honey at $75 \%$ in TSB, Manuka, Highland and Chilean honey were the most active, however an examination of the composition of each honey failed to indicate whether activity was due to high polyphenol and antioxidant capacity, or hydrogen peroxide activity as these were different for each honey. Although there was a significant reduction the growth of both strains of S.aureus by the sugar control, it is likely that inhibition of bacterial cell numbers by Manuka, Highland and Chilean honey is multifactorial possibly involving osmotic pressure on the bacterial membrane by sugar and the putative synergistic activity of a number of active polyphenols or other components of the honey [19,32]. Further this activity may be unrelated to the mechanism of action and active component(s) common in all seven honeys responsible for inhibition of TSST-1.

As stated, levels of antioxidants and polyphenols measured in this study varied between different honeys ranging from low (Capstone Valley blossom honey) to high (Buckwheat honey). Polyphenols are a vast group of molecules based on phenol, a well known antimicrobial agent, and differ between each other in structure, which can affect their respective properties [33]. In general, honeys with a high concentration of polyphenol and antioxidant activity tend to be dark in colour [22] which is in agreement with the results produced here. Brudzynski et al. [34] and Schneider et al. [13] reported that honeys with higher levels of polyphenols of greater antioxidant activity had greater antimicrobial activity against $E$. coli, S.aureus, P.aeruginosa and Acinetobacter calcoaceticus emphasizing that the difference in chemical structure of polyphenols is likely to be one of the determining factors of antibacterial activity. Interestingly, Brudzynski et al. [34] found that addition of catalase to honey, thus counteracting the hydrogen peroxide activity, significantly increased the minimum inhibitory concentration against $E$. coli and B. subtilis proportionally to their total phenolic content and antioxidant activity. This synergistic effect of polyphenols and hydrogen peroxide against bacteria was due to degradation of bacterial plasmid DNA. This however does not fully explain why Manuka honey and Highland honey were so antibacterial as these have a low hydrogen peroxide activity, but methylglyoxal which is present at high concentration in Manuka honey possibly contributed to activity in this particular honey [26].

In conclusion, this study has clearly demonstrated that all seven honeys strongly inhibit the production of S.aureus TSST-1, but not all of these honeys possess comparable inhibitory properties with respect to the reduction of bacterial cell numbers. This indicates that the mechanism(s) of antibacterial activity and toxin reducing ability are probably independent of each other. Clearly, new antimicrobial agents need to be developed to counter act the increase in bacterial resistance to antibiotics and putative anti-pathogenic agents such as honey may offer another strategy in the control of infection.

\section{Acknowledgements}

We are very grateful to Mrs Campbell and Mr Smith who funded this research. We are grateful to all our Beekeepers for their kind donation of honey. We are grateful for the technical assistance of Miss Shirley Coyle. There are no competing interests associated with this research. Ethical approval was given by the Division of Health Sciences Ethics Committee, Queen Margaret University.

\section{REFERENCES}

[1] Lowy, F.D. 1998. Staphylococcus aureus infections. New England Journal of Medicine, 339 (8) pp.520-532.

[2] Andrey, D.O., Renzoni, A., Monod, A.,Lew, D.P., 
Ambrose.L.C and Kelly, W.L. 2010. Control of the Staphyloccocus aureus toxic shock tst promoter by the global regulator SarA. J of Bacteriology, 192 (22),pp 6077-6085.

[3] Boyle-Vavra, S., Carey, R.B. and Daum, R.S. 2001. Development of vancomycin and lysostaphin resistance in a methicillin-resistant Staphylococcus aureus isolate. The Journal of Antimicrobial Chemotherapy, 48 (5) Nov, pp.617-625

[4] Qiu, J., Wang, D., Xiang, H., Feng, H., Jiang, Y., Xia, L., et al 2010. Subinhibitory concentrations of thymol reduce enterotoxins $\mathrm{A}$ and $\mathrm{B}$ and $\alpha$-hemolysin production in Staphylococcus aureus isolates. PLoS one, 5 (3) pp.e9736.

[5] Werner, G., Strommenger, B. and Witte, W. 2008. Acquired vancomycin resistance in clinically relevant pathogens. Future Microbiology(95) 547-562.

[6] Dinges, M.M., Orwin, P.M. and Schlievert, P.M. 2000. Exotoxins of Staphylococcus aureus. Clinical microbiology reviews, 13 (1) Jan, pp.16-34, table of contents.

[7] Lappin.E and Ferguson.A.J .2009. toxic shock syndrome (TSS) is an acute, multi- system toxin-mediated illness . Lancet. Infectious diseases 9.(5) pp 281-290

[8] Miethke, T., Duschek, K., Wahl, C., Heeg, K. and Wagner, H. 1993. Pathogenesis of the toxic shock syndrome: T cell mediated lethal shock caused by the superantigen TSST -1 . European Journal of Immunology, 23 (7) pp.1494-1500.

[9] Kramer, S. 1954. Levey. An older pharmacopoeia. JAMA, 155 (1) pp. 26.

[10] George, N.M. and Cutting, K.F. 2007. Antibacterial honey (Medihoney ${ }^{\mathrm{TM}}$ ): in-vitro activity against clinical isolates of MRSA, VRE, and other multiresistant Gram-negative organisms including Pseudomonas aeruginosa. Wounds, 19 (9) pp.231.

[11] Molan, P.C. 2006. The evidence supporting the use of honey as a wound dressing. The international Journal of Lower Extremity Wounds, 5 (1) Mar, pp.40-54.

[12] Kwakman, P.H., Te Velde, A.A., De Boer, L., Vandenbroucke-Grauls, C.M. and Zaat, S.A. 2011. Two major medicinal honeys have different mechanisms of bactericidal activity. PLoS One, 6 (3) pp.e17709.

[13] Schneider, M., Coyle, S., Warnock, M., Gow, I. and Fyfe, L. 2012. Anti - Microbial Activity and Composition of Manuka and Portobello Honey. Phytotherapy Research, 27 (8) pp.1162-1168.

[14] White Jr, J.W. 1957. The composition of honey . Bee World, 38 (3) pp57-66

[15] Adenekan,M.O., Amusa,N.A, Lawal,A.O and Okpeze,V.E. 2010. Physico-chemical and microbiological properties of honey samples.$J$ of Microbiol Antimicrobiol ,2, (8),pp100-104

[16] Kwakman, P.H., te Velde, A.A., de Boer, L., Speijer, D., Vandenbroucke-Grauls, C.M. and Zaat, S.A. 2010. How honey kills bacteria. FASEB journal : official publication of the Federation of American Societies for Experimental Biology, 24 (7) Jul, pp.2576-2582.

[17] Khan, F., Hill, J., Kaehler, S., Allsopp, M. and Vuuren, S. 2014. Antimicrobial properties and isotope investigations of
South African honey. Journal of Applied Microbiology,

[18] Carnworth.R., Graham.E.M., Reynolds.K and Pollock.P.J 2013. The antimicrobial activity of honey against common would isolates. The Veterinary Journal.10.1016.

[19] Fyfe,L, Armstrong.F and Stewart. J 1998. Inhibition of Listeria monocytogenes and Salmonella enteridits by combinations of plant essential oils and derivatives of benzoic acid ; the development of synergistic antimicrobial combinations. International Journal of Antimicrobial Agents .9. 195-199

[20] Smith-Palmer, A., Stewart, J. and Fyfe, L. 2002. Inhibition of Listeriolysin 0 and phosphatidylcholine specific production in Listeria monocytogenes by subinhibitory concentrations of plant essential oils, of plant essential oils on the production of enterotoxins $\mathrm{A}$ and $\mathrm{B}$ and alpha-toxin by Staphylococcus aureus. Journal of Medical Microbiology, $51, \mathrm{pp} 567$

[21] Smith-Palmer, A., Stewart, J. and Fyfe, L. 2004. Influence of subinhibitory concentrations of plant essential oils on the production of enterotoxins A and B and alpha-toxin by Staphylococcus aureus. Journal of Medical Microbiology, 53 (Pt 10) Oct, pp.1023-1027.

[22] Kaškonienè, V., Maruška, A., Kornyšova, O., Charczun, N., Ligor, M. and Buszewski, B. 2009. Quantitative and qualitative determination of phenolic compounds in honey. Chemine technologija, 52 (3) pp.74-80.

[23] Benzie, I.F. and Strain, J. 1996. The ferric reducing ability of plasma (FRAP) as a measure of "antioxidant power": the FRAP assay. Analytical Biochemistry, 239 (1) pp.70-76.

[24] Singleton, V. and Rossi, J.A. 1965. Colorimetry of total phenolics with phosphomolybdic-phosphotungstic acid reagents. American Journal of Enology and Viticulture, 16 (3) pp.144-158

[25] White Jr, J.W. and Subers, M.H. 1963. Studies on honey inhibine. 2. A chemical assay. J Apic Res, 2 pp.93-100.

[26] Kwakman, P.H., Te Velde, A.A., De Boer, L., Vandenbroucke-Grauls, C.M. and Zaat, S.A. 2011. Two major medicinal honeys have different mechanisms of bactericidal activity. PLoS One, 6 (3) pp.e17709.

[27] Jenkins, R.E., Burton, N., and Cooper, R. 2013. Proteomic and genomic analysis of methicillin-resistant Staphylococcus aureus (MRSA) exposed to manuka honey in vitro demonstrated down-regulation of virulence markers. Journal of Antimicrobial Chemtherapy, doi;10.1093. pp1-13

[28] James,J.F., Chu,M.C., Lee.L., Peck,S.A. ,McKissick,C., Sullivan, H., et al 1989. Effect of magnesium on in vitro production of toxic shock syndrome toxin-1. Reviews in Infectious Disease .Supplement 1,S157-166.

[29] Yarwood,J.M and Schlievert, P.M 2000. Oxygen and carbon dioxide regulation of toxic shock syndrome toxin1 production by Staphylococcus aureus MN8. Journal of Clinical Microbiology. 38 (5) pp1797-1803

[30] Chan,P.F and Foster.S.J 1998. The role of the environmental factors in the regulation of virulence -determinant expression in Staphylococcus aureus .Microbiology .144 (9)pp 2469-2479 
[31] van Langevelde,P ., van Dissel,j.T., Meurs.C.J.C Renz,J. and Groeneveld,P.H.P 1997 Antimicrobial agents and Chemotherapy .41,(8) 1682-1685

[32] Jenkins, R.E. and Cooper, R. 2012. Synergy between oxacillin and manuka honey sensitizes methicillin-resistant Staphylococcus aureus to oxacillin. The Journal of Antimicrobial Chemotherapy, 67 (6) Jun, pp.1405-1407.
[33] Cowan.M.M 1999. Plant products as antimicroibial agents . Clinical Microbiology Reviews, American Society of Microbiology, 12,(4) pp 564-582 1

[34] Brudzynski, K., Abubaker, K. and Miotto, D. 2012. Unraveling a mechanism of honey antibacterial action: Polyphenol $/ \mathrm{H}<$ sub $>2</$ sub $>\mathrm{O}<$ sub $>2</$ sub $>$-induced oxidative effect on bacterial cell growth and on DNA degradation. Food Chemistry, 133 (2) pp.329-336. 